\title{
Homofobia w paragrafach. Rzecz o relacjach prawodawstwa, dyskursu $i$ postaw społecznych w Rosji
}

Blisko połowa Rosjan deklaruje swój negatywny stosunek do osób homoseksualnych. Z danych Centrum im. Jurija Lewady wynika, że najczęstszymi uczuciami żywionymi do mniejszości seksualnych są wstręt i strach, a w dalszej kolejności rozdrażnienie. Spokojnie i bez emocji odnosi się do nich ledwie jedna czwarta respondentów ${ }^{1}$. Badani zadeklarowali też zdecydowanie negatywną reakcję na konieczność pracy z osobą homoseksualną, bycia jej sąsiadem lub gdyby okazał się nią bliski przyjaciel bądź ktoś z rodziny ${ }^{2}$. Jeżeli do powyższych dodać jeszcze, że $58 \%$ odmawia dorosłym ludziom możliwości wchodzenia w dobrowolne kontakty homoseksualne, otrzymamy obraz społeczeństwa silnie homofobicznego.

Zjawisko homofobii nie jest obce żadnemu współczesnemu społeczeństwu. Manifestacje przeciwko przyznawaniu kolejnych praw osobom LGBT zdarzają się także w zachodnich krajach o ugruntowanej demokracji. Jednak tym, co różni je od sytuacji rosyjskiej, jest skala takich zachowań oraz stosunek władz, które na poziomie stanowionego prawa oraz stosowanej retoryki są nie mniej homofobiczne od ogółu społeczeństwa. Jak przekonuje Jacek Kochanowski, kluczowy wpływ na stosunek do osób homoseksualnych mają wydarzenia polityczne, które narzucają ton publicznego dyskursu. Antyhomoseksualna retoryka przekłada się zazwyczaj na pogorszenie wskaźni-

${ }^{1}$ Невидимое миеншиство - $к$ проблеме гомофобии в России, www.levada.ru/2015/05/05/ nevidimoe-menshinstvo-k-probleme-gomofobii-v-rossii/ [dostęp: 15 maja 2016].

2 Odpowiednio 44, 41 i $48 \%$ odpowiedzi. Dwa pierwsze warianty bez emocji przyjęłoby $27 \%$ badanych. Trudniej byłoby się Rosjanom pogodzić z homoseksualistą w bliskim otoczeniu — reakcję bez emocji zadeklarowało ledwie 17 procent badanych - ibidem. 
ków społecznej akceptacji dla mniejszości ${ }^{3}$. Tłumaczyłoby to powolny, ale stały spadek przyzwolenia na homoseksualność w Rosji. Tylko między 2005 a 2013 rokiem odnotowano jego obniżenie o siedem punktów procentowych, podczas gdy w analogicznym okresie grono zwolenników leczenia, a także izolowania homoseksualistów zwiększyło się o cztery punkty procentowe ${ }^{4}$. Niepokoi także wzrost do pięciu procent zwolenników „fizycznej likwidacji” " Znaczące, że opisywane wyżej przesunięcia dokonały się w okresie uchwalania pierwszych regionalnych „zakazów propagandy homoseksualnej wśród niepełnoletnich" oraz procedowania nad analogicznym zakazem na poziomie ogólnokrajowym.

\section{Radzieckie dziedzictwo}

Aby umiejscowić w szerszym kontekście stosunek Rosjan do homoseksualności, niezbędne jest cofnięcie się do okresu radzieckiego, w którym większość społeczeństwa podlegała socjalizacji. Na mocy postanowienia Prezydium Centralnego Komitetu Wykonawczego ZSRR z 17 grudnia 1933 r. dokonano nowelizacji kodeksu karnego, wprowadzając artykuł $154^{6}$ przewidujący karę 3-5 lat łagru za dobrowolne analne stosunki seksualne między mężczyznami ${ }^{7}$.

Szacuje się, że przez cały okres obowiązywania przepisów do więzień trafiło co najmniej 60 tys. osób ${ }^{8}$. Warto jednak zauważyć, że wspomniane artykuły bardzo chętnie wykorzystywano do walki z dysydentami, więc nie można bezpośrednio utożsamiać tych danych z liczbą skazanych homoseksualistów. Oskarżenie o czyny określane mianem kontrrewolucyjnych oraz będących przejawem moralnej zgnilizny burżuazji było dodatkową formą napiętnowania przed społeczeństwem, a także musiało skutkować ostracyzmem ze strony współwięźniów.

Depenalizacji homoseksualności dokonał dopiero Borys Jelcyn 27 maja 1993 roku Decyzja ta była jednak bardziej wynikiem presji Rady Europy, do członkostwa w której Rosja wówczas aspirowała, niż efektem głębszych przemian społecznych czy politycznych, gdyż jeszcze w 1992 roku do więzień trafiło 227 osób skazanych na mocy artykułu 121.

3 J. Kochanowski, Przedmowa do wydania polskiego, [w:] S. Seidman, Społeczne tworzenie seksualności, Warszawa 2012, s. 19.

${ }^{4}$ W lutym 2013 roku tę opcję wybrało odpowiednio 22 i 16\% badanych - Н. Зоркая, Общественное мнение - 2013, Moskwa 2014, s. 116.

5 Ibidem, s. 115.

6 Po nowelizacji Kodeksu Karnego w 1960 roku przepis ten znalazł się pod numerem 121.

7 Na terytorium Rosji nigdy nie karano za żeńskie kontakty homoseksualne ani oralne stosunki między mężczyznami. Д. Хили, Гомосексуальное влечение в революиионной России, Moskwa 2008, s. 225 .

${ }^{8}$ Niektóre szacunki mówią nawet o 250 tys. skazanych — ibidem, s. 311. 
Mylne i nadmiernie idealistyczne okazały się przypuszczenia, że depenalizacja pociągnie za sobą dalsze zmiany w stosunku do osób homoseksualnych. Próbę jego zobrazowania w pierwszych latach rosyjskiej niepodległości najlepiej ilustrowałaby sinusoida, w której każdemu pozytywnemu wydarzeniu towarzyszyłaby represyjna odpowiedź.

\section{Dwadzieścia lat prawnej homofobii}

Chcąc prześledzić homofobię na poziomie prawnym w dzisiejszej Rosji, musimy się cofnąć do uchwalonej 12 grudnia 1993 roku ustawy zasadniczej, która choć nie wspomina $\mathrm{w}$ żadnym miejscu o kategorii orientacji seksualnej ani nie definiuje małżeństwa jako związku kobiety i mężczyzny, czyni furtkę do ograniczenia swobód obywatelskich. Artykuł 55 pkt 2. stanowi, że:

Prawa i wolności człowieka mogą zostać ograniczone przez ustawę federalną jedynie w takiej mierze, w jakiej jest to niezbędne do ochrony podstaw ustroju konstytucyjnego, m o r a l n o ś c i, zdrowia, praw i uprawnionych interesów innych osób ${ }^{9}$.

Między innymi z uwagi na te zapisy bezskuteczne okażą się w przyszłości próby zaskarżania konstytucyjności ustaw uderzających w społeczność LGBT.

Przełomowym wydarzeniem w historii rosyjskich homoseksualistów był 1 stycznia 1999 roku, gdy Ministerstwo Zdrowia oficjalnie zaaprobowało nową klasyfikację chorób ICD-10, dzięki czemu homoseksualność przestała być - w świetle przepisów - uważana za chorobę. Jakkolwiek decyzja ta z pozoru mogłaby zostać uznana za przejaw liberalizacji, to szerszy kontekst każe wątpić w taką interpretację. Klasyfikacja weszła bowiem w życie osiem i pół roku po jej przyjęciu 17 maja 1990 roku przez Światową Organizację Zdrowia ${ }^{10}$. Co więcej, wciąż obowiązywała instrukcja Ministerstwa Zdrowia z 29 maja 1995 roku zakazująca homoseksualistom honorowego oddawania $\mathrm{krwi}^{11}$, którą wycofano dopiero 16 kwietnia $2008 \mathrm{roku}^{12}$. Nie dziwi zatem, że wciąż $37 \%$ badanych uważa homoseksualność za chorobę ${ }^{13}$, a wartość ta utrzymuje się od lat na podobnym poziomie ${ }^{14}$.

9 Konstytucja Rosji, przeł. A. Kubik, Warszawa 2000.

10 Polska zaaprobowała nowe rozwiązania już w 1996 roku.

11 Невидимое миеншиство...

12 Приказ Минздравсоцразвития России № 175н от 16 апреля 2008 г., http://goo.gl/QxACLO [dostęp: 15 maja 2016].

13 Badanie Centrum im. Jurija Lewady z kwietnia 2013 roku, http://goo.gl/1f0cSd [dostęp: 15 maja 2016].

14 Najniższe wskaźniki odnotowano w 2001 i 2005 roku - W. Sitarz, Od depenalizacji do zakazów propagandy. Statystyczne ujęcie przemian w postrzeganiu homoseksualności w Rosji, [w:] A. Majewska, (R)ewolucje: zmiany w republikach postradzieckich, Kraków 2015, s. 186. 
Lata 90. są czasem powolnego rozwoju aktywizmu LGBT. Początki jednak nie były proste - w sierpniu 1993 roku moskiewski sąd nie zgodził się na rejestrację ogólnokrajowej organizacji „Trójkąt” zrzeszającej osoby nieheteroseksualne, argumentując, że przeczy ona „społecznym normom moralności” ${ }^{15}$. Organizacje, którym ostatecznie udało się powstać, skupiały się w pierwszej kolejności na doraźnej pomocy osobom homoseksualnym, a w szczególności zakażonym wirusem HIV, w mniejszym zaś na lobbingu za zmianą niekorzystnych przepisów. Wraz ze stopniowym upowszechnianiem się internetu rozpoczął się proces przenoszenia aktywności do sieci, który czasem określa się mianem drugiej fali LGBT-aktywizmu ${ }^{16}$. Powstało wówczas wiele portali dedykowanych gejom, lesbijkom oraz osobom poszukującym partnerów, informacji lub wsparcia.

\section{Zakazy propagandy}

Równolegle z rozwojem ruchu nie słabły głosy domagające się powrotu do rozwiązań radzieckich i rekryminalizacji homoseksualności. W 2002 roku grupa parlamentarna Hapoдныц деnymam próbowała wprowadzić pod obrady Dumy Państwowej projekt wzorowany na uchylonych dziewięć lat wcześniej przepisach. Przewidywał on do pięciu lat pozbawienia wolności za homoseksualne stosunki między mężczyznami ${ }^{17}$. O ile wprowadzenie ustaw uderzających w osoby homoseksualne nie powiodło się na federalnym poziomie, o tyle począwszy od 2006 roku w kolejnych jednostkach administracyjnych zaczęto uchwalać lokalne prawa zakazujące tzw. propagandy homoseksualizmu.

Jako pierwsi z możliwości ograniczenia swobody wypowiedzi w imię moralności skorzystali deputowani obwodu riazańskiego położonego na południowy wschód od Moskwy. Podpisana 15 czerwca 2006 roku nowelizacja Kodeksu Wykroczeń Administracyjnych zakłada karanie za „publiczne akcje, skierowane na propagandę homoseksualizmu (gejowstwa i lesbijstwa) wśród niepełnoletnich" ${ }^{18}$.

Katalog kar za wspomniane wykroczenie przewiduje od 1,5 tys. rubli dla osób fizycznych do 20 tys. dla osób prawnych ${ }^{19}$.

Uchwalenie precedensowego prawa spotkało się ze zdecydowanym sprzeciwem organizacji zrzeszających mniejszości seksualne. Najbardziej jaskrawym przypadkiem sprzeciwu była akcja Iriny Fiedotowej i Nikołaja Bajewa. Wyszli oni na ulice

15 В. Созаев, ЛГБТ - Люди с историей, [w:] История, praca zbiorowa, Petersburg 2011, s. 20.

16 Ibidem.

17 Райков требует вернуть смертную казнь и запретить гомосексуализм, http://goо.gl/ Q8Mv55 [dostęp: 15 maja 2016].

18 Prawo Obwodu Riazańskiego z 15 czerwca 2006 Nr 66-O3.

19 W pierwotnym brzmieniu kary wyrażone były w wielokrotnościach minimalnego wynagrodzenia. Aktualnie obowiązujące kwoty są wynikiem nowelizacji Kodeksu. 
Riazania, trzymając w rękach plakat z napisami „Homoseksualność jest normalna” oraz „Jestem dumny ze swojej homoseksualności. Zapytaj mnie o to”. Przeprowadzona 30 marca 2009 roku akcja nie umknęła uwadze milicji, która zatrzymała oboje demonstrantów pod zarzutem propagowania homoseksualizmu, gdyż w trakcie akcji przechodzili oni m.in. obok budynku szkoły średniej. W wyniku procesu, 6 maja 2009 roku uznano aktywistów winnymi i wymierzono karę $1500 \mathrm{rubli}^{20}$, a wyrok stał się tym samym pierwszym w Rosji przypadkiem ukarania za propagowanie homoseksualizmu ${ }^{21}$.

Fiedotowa i Bajew byli członkami powołanej 17 maja 2005 roku w Moskwie organizacji GayRussia.Ru, której powstanie otwiera trzecią falę LGBT-aktywizmu. Kierowany przez Nikołaja Aleksiejewa ruch za główne zadanie stawia sobie wprowadzenie tematyki LGBT do agendy medialnej m.in. przez próby przeprowadzania parad równości w Moskwie oraz manifestacji w innych regionach kraju. Pierwsze „Moscow Pride" miało się odbyć w trzynastą rocznicę depenalizacji homoseksualizmu, jednak władze odmówiły rejestracji zgromadzenia. Mimo braku formalnej zgody aktywiści usiłowali złożyć kwiaty przy wiecznym ogniu u ścian Kremla i przeprowadzić w pobliżu krótki wiec. Spotkało się to ze zdecydowaną reakcją sił porządkowych, które rozpędziły zgromadzonych.

W kolejnych latach sytuacja się powtarzała. GayRussia składało wnioski, które spotykały się z odmową, wobec czego aktywiści próbowali przeprowadzać akcje wbrew zakazowi. Brak rejestracji każdorazowo argumentowano napływającymi do merostwa głosami przedstawicieli organów państwowych, wyznań religijnych, organizacji społecznych i poszczególnych obywateli z prośbą o niewyrażanie zgody na takie publiczne zgromadzenia. Administracja podnosiła też, że istnieje zagrożenie kontrmanifestacjami, które mogłyby się przerodzić w masowe naruszenia społecznego porządku. Wątpliwości co do prawdziwych intencji władz rodzą jednak wypowiedzi ówczesnego mera Moskwy Jurija Łużkowa, który odnosząc się do działań aktywistów, stwierdzał:

od kilku lat mamy do czynienia $\mathrm{z}$ bezprecedensowym naciskiem na Moskwę z żądaniem zorganizowania tu gej-parady, której inaczej jak szatańskim działaniem nazwać nie można. Nie wyraziliśmy i nie wyrazimy zgody na taką paradę. Wszyscy muszą to uznać nie jako twierdzenie, ale jako pewnik ${ }^{22}$.

20 Комитет ООН по правам человека признал российские запреты гей-пропаганды нарушающими Пакт о гражданских и политических правах, http://www.gayrussia.eu/russia/5280/ [dostęp: 15 maja 2016].

21 Więcej o praktyce sądowej związanej z „zakazami propagandy homoseksualizmu” zob. W. Sitarz, Zakazy propagandy homoseksualnej w Rosji - praktyka sądowa, [w:] Różni w życiu, równi w prawach. Równość w polityce lokalnej, red. J. Podgórska-Rykała, Wrocław 2013.

22 Лужков: запрет гей-парадов надо принять как аксиому, http://www.newsmsk.com/article/25Jan2010/aksioma.html [dostęp: 15 maja 2016]. 
W wyniku skargi Nikołaja Aleksiejewa w sprawie odmowy rejestracji parad w latach 2006-2008 wypowiedział się Europejski Trybunał Praw Człowieka. Orzekł on, że moskiewskie władze naruszyły artykuły 11, 13, i 14 Europejskiej Konwencji o Ochronie Praw Człowieka i Podstawowych Wolności odnoszące się do wolności zgromadzeń i stowarzyszania się, prawa do skutecznego środka odwoławczego oraz zakazu dyskryminacji. Trybunał uznał, że samo ryzyko niepokojów związanych z kontrmanifestacjami nie może uzasadniać odmowy rejestracji zgromadzenia, ponieważ obowiązek ochrony pokojowych manifestacji spoczywa na władzach publicznych. Ponadto argumentowano, że nie można uzasadniać ograniczania prawa do manifestacji przez mniejszości brakiem aprobaty dla jej postulatów przez większość ${ }^{23}$.

Werdykt ostatecznie wszedł w życie po oddaleniu rosyjskiej apelacji 14 kwietnia 2011 roku, ale mimo wypłaty zasądzonego odszkodowania oraz zmiany na stanowisku mera stolicy sytuacja $\mathrm{z}$ odmową rejestracji zgromadzeń powtarza się w Moskwie rokrocznie. Nie pomogła także zmiana przyjętej taktyki i próby przeprowadzania manifestacji w hyde-parkach na obrzeżach centrum. Choć teoretycznie na akcje w takich miejscach nie trzeba uzyskiwać zgody, a jedynie zarezerwować wolny termin, to w maju 2013 roku początkowo odmówiono rejestracji, a po odwołaniu od decyzji w przededniu planowanej akcji zamknięto wszystkie hyde-parki z uwagi na „konieczność remontu”.

\section{(Nie)skuteczność strategii i seksualna panika}

Opisana sytuacja każe zastanowić się nad skutecznością stosowanej przez część aktywistów litygacji strategicznej. Nie brak głosów, że w rosyjskiej rzeczywistości organizowanie parad jest nie tylko nieskuteczne, ale wręcz przynosi skutek odwrotny od zamierzonego, mobilizując skrajnie ksenofobiczne organizacje i populistycznych polityków do wywoływania paniki seksualnej. Daleki od niechęci dla społeczności LGBT zasłużony badacz seksualności Igor Siemionowicz Kon stawiał wręcz zarzut, że tego typu działania są nastawione nie na przekonywanie Rosjan, lecz przyciągnięcie uwagi zagranicznych korespondentów ${ }^{24}$. To, co wedle zachodnich norm było zupełnie normalne, w rosyjskim pojęciu jest „europejskim show, obliczonym na europejskiego widza" 25 . Wrogo odnoszący się do zachodu Rosjanie odbierają działania aktywistów jako prowokację zorganizowaną $\mathrm{w}$ celu popsucia reputacji ich kraju, a władze centralne dodatkowo podsycają tego typu nastroje.

23 Sprawa Alekseyev przeciw Rosji z 21 listopada 2010 roku (Skargi nr 4916/07, 25924/08 i 14599/09).

24 I. Kon, Сексуальная культура в России: клубничка на березке, http://sexology.narod.ru/ chapt605.html [dostęp: 15 maja 2016].

25 I. Kon, Лакмусовая бумажка российской демократии, http://sexology.narod.ru/infol70.html [dostęp: 15 maja 2016]. 
Za poparciem tezy o nieskuteczności strategii przyjętej przez część rosyjskiego ruchu LGBT mogłoby przemawiać też, że w ślady obwodu riazańskiego poszły, mimo protestów, kolejne regiony. Tylko w 2012 roku regionalne zakazy propagandy homoseksualnej uchwalono w siedmiu podmiotach Federacji Rosyjskiej, a w kolejnym roku do tego grona dołączyły jeszcze dwa obwody.

We wspomnianym okresie Rosję ogarnęła swoista panika seksualna, zjawisko charakteryzowane przez badaczy jako nadmiernie emocjonalna reakcja na wyimaginowane zagrożenie, u której podstaw leży strach przed różnorodnością. Homoseksualiści stali się symbolem, kozłem ofiarnym reprezentującym szeroki wachlarz kulturowych i politycznych lęków - w rzeczywistości podzielanych bądź będących wynikiem koniunkturalnego wykreowania przez polityków usiłujących zbić kapitał na nośnym haśle ochrony dzieci ${ }^{26}$.

O tym, że działania władz były skuteczne, najlepiej świadczą dane statystyczne -61\% Rosjan boi się, że ich dzieci mogłyby się stać ofiarami propagandy homoseksualizmu. Wysokiego poziomu strachu nie zmienia nawet, że $\mathrm{w}$ innym badaniu tylko $18 \%$ respondentów uznała, że ich własna orientacja mogłaby się zmienić w dzieciństwie pod wpływem propagandy ${ }^{27}$. Fali nowych zakazów nie powstrzymał także werdykt Komitetu Praw Człowieka ONZ, który 31 października 2012 roku uznał rosyjskie prawodawstwo za naruszające Międzynarodowy Pakt Praw Obywatelskich i Politycznych ${ }^{28}$. W efekcie do połowy 2013 roku „zakazy propagandy homoseksualizmu wśród niepełnoletnich" uchwalono w jedenastu regionach ${ }^{29}$, obejmując blisko 27 milionów ludności ${ }^{30}$.

W miarę rozszerzania się obszaru obowiązywania homofobicznego prawodawstwa coraz częściej zaczęto mówić o konieczności uchwalenia zakazu na poziomie całej Federacji. Z inicjatywy deputowanych okręgu nowosybirskiego do Dumy Państwowej wpłynął projekt ogólnorosyjskiego prawa o „zakazie propagandy homoseksualizmu wśród niepełnoletnich", będącego wierną kopią przyjętych w Nowosybirsku rozwiązań. Procedowanie nad ustawą trwało przez całe pierwsze półrocze 2013 roku. $\mathrm{W}$ efekcie powstał zestaw nowelizacji pod zmienioną nazwą „o ochronie dzieci przed informacjami propagującymi kwestionowanie tradycyjnych wartości rodzinnych". Jednak zawarcie w tekście artykułów traktujących o „propagandzie nietradycyjnych stosunków seksualnych", będących czytelnym eufemizmem na pojęcie homoseksualizmu, nie pozostawia wątpliwości odnośnie do prawdziwych intencji prawodawców.

26 Por. B. Shepard, Queer Political Performance \& Protest, New York 2010, s. 200.

27 Н. Зоркая, ор. cit., s. 117, 119.

28 Był to efekt skargi Iriny Fiedotowej na decyzje skazujące ją za protesty w Riazaniu.

29 W kolejności uchwalania: obwody riazański, archangielski, kostromski, miasto Petersburg, obwody magadański i nowosybirski, Kraj Krasnodarski, obwód samarski, Republika Baszkortostanu, obwody kaliningradzki i irkucki.

30 Stanowi to 18,75\% ogółu mieszkańców Rosji — opracowanie własne na podstawie danych Federalnej Służby Statystyki Państwowej, http://goo.gl/UPkqZh [dostęp: 15 maja 2016]. 
W myśl artykułu 6.21 za propagandę uważa się:

rozprzestrzenianie informacji nastawionej na formowanie u niepełnoletnich nietradycyjnych orientacji seksualnych, wrażenia atrakcyjności nietradycyjnych stosunków seksualnych oraz zniekształconego obrazu o społecznej równowartości tradycyjnych i nietradycyjnych związków seksualnych albo narzucanie informacji wzbudzającej zainteresowanie takimi związkami ${ }^{31}$.

Za wymienione przewinienia grozi od 4 do 5 tys. rubli dla osób fizycznych, 40-50 tys. dla osób wykonujących obowiązki służbowe i 800 tys. -1 miliona rubli dla osób prawnych. Ustawa przewiduje też, że jeżeli do propagandy dochodziłoby w środkach masowego przekazu, kary wzrastają do odpowiednio: 50-100 tys., 100-200 tys. i do 1 miliona rubli. Ponadto dla obcokrajowców oprócz grzywny stosuje się deportację. Niezwykle istotny jest zapis odnoszący się do penalizacji propagandy medialnej. Inkluzywna definicja propagandy oraz praktyka sądowa sprawia, że de facto obowiązuje w Rosji cenzura represyjna w odniesieniu do pozytywnego informowania o homoseksualności. Tym groźniejsze, bo niemierzalne, jest wymuszanie autocenzury skłanianie dziennikarzy, aby na wszelki wypadek nie zajmowali się tym tematem, bo potencjalnie mogą za swoją pracę trafić przed wymiar sprawiedliwości.

Dla deputowanych ważniejsze od protestów towarzyszących uchwalaniu nowego prawa okazało się poparcie wyrażane przez większość rosyjskiego społeczeństwa. Badanie przeprowadzone przez Centrum im. Jurija Lewady wykazało, że aż $76 \%$ respondentów popiera zakazy propagandy homoseksualizmu ${ }^{32}$. Wychodząc naprzeciw oczekiwaniom wyborców po niemal jednogłośnym przyjęciu ustaw przez Dumę Państwową ${ }^{33}$ i Radę Federacji, prezydent Wladimir Putin podpisał je 29 czerwca, a prawo weszło $\mathrm{w}$ życie $\mathrm{w}$ dniu jego opublikowania następnego dnia.

Ważnym kontekstem, który może rzucić więcej światła na poczytania rosyjskiego prawodawcy, może być koncepcja zwrotu konserwatywnego ${ }^{34}$. Cześć rosjoznawców zauważa, że wraz z powrotem Wladimira Putina na stanowisko prezydenta w 2012 roku w dyskursie polityki coraz częściej zaczęto eksploatować elementy ideologii konserwatywnej, a obronę tzw. tradycyjnych wartości zaczęto przedstawiać jako główny cel rządów ${ }^{35}$. Przemianom na poziomie języka towarzyszyło zainicjowanie wielu ustaw, wśród których ważne miejsce miała właśnie nowelizacja dotycząca zakazu propagandy.

31 Федеральный закон от 29.06.2013 № 135-Ф3, http://goo.gl/QBEW1p [dostęp: 15 maja 2016].

32 Badanie na grupie 1601 respondentów przeprowadzono w czerwcu 2013 roku, http://goo.gl/ Jsp7oA [dostęp: 15 maja 2016].

$33 \mathrm{~W}$ drugim czytaniu za przyjęciem ustaw głosowało 436 deputowanych, nie poparł jej jedynie Ilja Ponomariow z frakcji Sprawiedliwa Rosja, który wstrzymał się od głosu, http://vote.duma.gov.ru/ vote/81454 [dostęp: 15 maja 2016].

34 Szerzej: W. Sitarz, Rewolucja tradycji. Zwrot konserwatywny jako strategia Kremla w polityce wewnętrznej i zagranicznej, „Wschodnioznawstwo” 2016, s. 257-270.

35 Por. W. Rodkiewicz, J. Rogoża, Potiomkinowski konserwatyzm, Warszawa 2015. 


\section{Społeczny oddźwięk}

Jak zauważono we wstępie, homofobiczna polityka prowadzona przez władze każdorazowo pociąga za sobą skutki w stosunku ogółu społeczeństwa do mniejszości. Ich najbardziej jaskrawym przejawem są nasilające się ataki na osoby LGBT. Tylko podczas pięciu miesięcy, jakie upłynęły między pierwszym a drugim czytaniem ustaw o zakazie propagandy, donoszono o dwudziestu sześciu przypadkach pobić motywowanych orientacją seksualną, z których siedem zakończyło się śmiercią ofiar - często w bardzo brutalnych okolicznościach ${ }^{36}$. Co więcej, można założyć, że w rzeczywistości ataków było więcej, ale nie zostały one zgłoszone, zwłaszcza że zdarzały się przypadki pobić na samych komisariatach.

Skuteczną walkę z przemocą motywowaną homofobicznie utrudnia niedoskonałość rosyjskiego prawa, nie ma w nim bowiem przepisów karzących za nienawiść motywowaną orientacją seksualną. Co więcej, praktyka sądowa pokazuje, że prokuratorzy na ogół nie chcą stosować w podobnych przypadkach przepisów o nienawiści do grup społecznych, uważając, że homoseksualiści się do nich nie zaliczają. Stąd większość postępowań w sprawie napadów na osoby LGBT toczy się w oparciu o zagrożone mniejszą karą przepisy o chuligaństwie. Ponadto nie ma też przyzwolenia społecznego na objęcie mniejszości seksualnych taką ochroną - badania pokazują, że 37\% Rosjan deklaruje sprzeciw wobec wprowadzenia zakazu dyskryminacji i wzbudzania nienawiści na tle orientacji seksualnej ${ }^{37}$.

Przejawem wzrostu nastrojów homofobicznych są także żądania zwolnienia z pracy homoseksualistów oraz popierających ich osób. W lutym 2013 roku na ogrodzeniu zasłużonego moskiewskiego liceum „Druga Szkoła” pojawiły się plakaty ze zdjęciem jednego z nauczycieli i napisami "To Ilja Kolmanowski, on deprawuje twoje dziecko” oraz „Sodomici won ze szkoły!”38. Była to odpowiedź na wywiad pedagoga w radiu Swoboda ${ }^{39}$, w którym ten przyznał się, że uczestniczył w demonstracji pod Dumą Państwową przeciwko zakazowi propagandy. W reakcji na protesty rodziców sprzeciwiających się uczeniu ich dzieci przez geja ${ }^{40}$ dyrekcja początkowo zadeklarowała zwolnienie nauczyciela, jednak ostatecznie wycofano się z tej decyzji, a pogłoski o wyrzuceniu zdementowano na oficjalnej stronie internetowej szkoły. Jednak obecnie Kolmanowski nie widnieje już w spisie nauczycieli, a z działu aktualności usunięto wcześniejsze oświadczenie ${ }^{41}$.

36 С. Медведев, Каминг-аут РФ: как гомобобия стала нашей национальной идеей, http://goо. gl/1XLGJG [dostęp: 15 maja 2016].

37 Н. Зоркая, ор. cit., s. 118.

38 «Это Илья Колмановский, он развращает твоего ребенка». Атака на учитклья «Второй школь» продолжается, http://goo.gl/fozrTe [dostęp: 15 maja 2016].

39 Rosyjska wersja Radia Wolna Europa.

$40 \mathrm{~W}$ rzeczywistości Kolmanowski nie jest gejem, a jedynie wspiera ruch LGBT.

41 http://goo.gl/iJ5zcU [dostęp: 15 maja 2016]. 
Z podobnym przykładem napiętnowania z powodu wspierania postulatów LGBT mieliśmy do czynienia w Petersburgu. Do komitetu ds. oświaty wpłynął donos na Jekaterinę Bogacz, nauczycielkę hiszpańskiego w gimnazjum nr 67, działaczkę Aliansu Heteroseksualistów na rzecz Równouprawnienia LGBT. Choć postępowanie prokuratorskie nie stwierdziło ostatecznie przypadków propagowania homoseksualizmu w szkole, to warta odnotowania jest reakcja Naczelnika Oddziału ds. Oświaty Nikołaja Smirnowa. Oświadczył on w rozmowie z mediami: „Podobne sytuacje rzutują na reputację nie tylko nauczyciela, ale i szkoły oraz całego systemu kształcenia. [...] Dla Bogacz wyrażenie własnego stanowiska jest ważniejsze niż autorytet szkoły czy nauczycielskiej społeczności" ${ }^{\prime 2}$. Z wypowiedzi jasno wypływa przesłanie do nauczycieli, że nawet poza murami szkoły muszą powstrzymać się od realizowania prawa do wypowiedzi.

O ile w sytuacji Petersburga i Moskwy dyrekcja starała się zachować co najmniej neutralność, to już w mniejszych miejscowościach żądania przynosiły oczekiwany skutek. We wrześniu 2013 roku w odpowiedzi na protesty rodziców i ultimatum dyrekcji zwolniła się z pracy Olga Bachajewa, nauczycielka historii z Magnitogorska ${ }^{43}$. W tym samym okresie z pracy odszedł również nauczyciel geografii z Chabarowska Aleksander Jermoszkin, wcześniej zawieszony z uwagi na protesty związane $\mathrm{z}$ jego orientacją ${ }^{44}$. Jego sprawa miała także dalszą odsłonę, ponieważ Roskomnadzor ${ }^{45}$ wytoczył proces za propagowanie homoseksualizmu lokalnej gazecie „Молодой Дальневосточник", która przeprowadziła wywiad z Jermoszkinem ${ }^{46}$. Sąd pierwszej instancji 30 stycznia 2014 roku skazał redaktora naczelnego Aleksandra Suturina na 50 tys. rubli grzywny ${ }^{47}$.

\section{Zgubny wpływ Zachodu}

Na interesujący kontekst uchwalenia ustawy zakazującej propagowania homoseksualizmu wskazuje badanie dotyczące domniemanych motywacji ustawodawcy. Szczególnie zastanawiająca jest druga najczęściej wskazywana odpowiedź — „nieodzowność przeciwdziałaniu zgubnemu wpływowi zachodu", z którą zgadza się $46 \%$ badanych $^{48}$.

42 Петербургская учительнииа: икола, донос и ЛГБТ, http://goo.gl/cPYeKl [dostęp: 15 maja 2016].

43 Учительнииа - „извращенка” из Магнитогорска, заявивщая о поддержке ЛГБТ, все-таки уволилась из школь, http://goo.gl/j7Wulq [dostęp: 15 maja 2016].

44 В Хабаровске учителя хотят уволить из-за его нетрадиционной ориентации, http://gоо. gl/IvP0z3 [dostęp: 15 maja 2016].

45 Federalna Służba ds. nadzoru w obszarze Komunikacji, Informacji, Technologii i Mediów — odpowiednik polskiej Krajowej Rady Radiofonii i Telewizji.

46 Эффективное доказательство ненормальности, http://goo.gl/jRNMyM [dostęp: 15 maja 2016].

47 Газету топят за „гей-пропаганду”, http://goo.gl/ImfRRf [dostęp: 30 stycznia 2014].

48 Россияне о новых консервативных законах, http://goo.gl/dt1x8X [dostęp: 15 maja 2016]. 
Można ją uznać za efekt swoistego antyokcydentalizmu rządów Wladimira Putina, którego sztandarowym przykładem jest prawo o „zagranicznych agentach" ${ }^{4}$, jeden z elementów wspomnianego wyżej zwrotu konserwatywnego. Jednymi z pierwszych ofiar nowej ustawy zostały petersburska organizacja LGBT Buxod i festiwal filmów LGBT $^{50}$. Choć ostatecznie sądy wyższej instancji oczyściły je z zarzutów w październiku i listopadzie 2013 roku, to sam fakt oskarżeń był przejawem spychania inaczej myślących na margines życia społecznego. Już samo istnienie takich przepisów presuponuje, niczym w latach ZSRR, że ruch opozycyjny jest ciałem obcym na rosyjskiej tkance ${ }^{51}$. Marginalizacja jeszcze silniej uwidacznia się na przykładzie ruchów LGBT. Ich miejsce znajduje się bowiem na skraju owego marginesu, przez brak wyraźnego poparcia dla ich postulatów ze strony antykremlowskiej opozycji ${ }^{52}$. Procesy zakończone wysokimi grzywnami, a następnie uniewinnienie po kilku miesiącach można ponadto uznać za przejaw demonstracji siły Kremla. Władza pokazuje w ten sposób, że jest w stanie łatwo uciszyć aktywistów, jeżeli będą oni dla władz zbyt niewygodni.

$\mathrm{Za}$ - z pozoru pozytywny - skutek wprowadzonych w 2013 roku homofobicznych ustaw można byłoby uznać upublicznienie na arenie międzynarodowej spraw społeczności LGBT w Rosji. Poparcie dla działań aktywistów wyrażają otwarcie politycy i ludzie show-biznesu, a wszelkim zagranicznym wyjazdom Wladimira Putina oraz osób go wspierających towarzyszyły protesty obrońców praw człowieka. Jednak zasadne wydaje się zastanowienie, czy wsparcie Zachodu może jakkolwiek pomóc w zmianie sytuacji rosyjskich homoseksualistów? Niebagatelną sprawą jest świadomość wsparcia dla wyznawanych przez LGBT-aktywistów idei, wątpliwe jednak, czy zachodnia opinia publiczna może mieć wpływ na rosyjskie władze w sprawie liberalizacji prawa. Wszelkie protesty są wodą na młyn dla głoszonej w mediach narracji o fundamentalnej odrębności wartości podzielanych w Rosji i na Zachodzie, będącej kluczową tezą zwrotu konserwatywnego. Ponadto mniejszościom seksualnym doczepiana jest łatka środowiska, które niszczy opinię o swoim kraju za granicą, a to jeszcze silniej uwidacznia podział swoi (heteroseksualni Rosjanie)-obcy (zwesternizowani homoseksualiści).

49 Uchwalona 20 lipca 2012 roku nowelizacja przepisów o organizacjach niekomercyjnych zobowiązuje je do rejestracji w charakterze „zagranicznego agenta” w sytuacji, gdy pobierają jakąkolwiek pomoc zagraniczną.

${ }^{50}$ Obie organizacje oraz ich dyrektorzy zostali skazani w pierwszych instancjach na kary kilkuset tysięcy rubli.

51 W. Sitarz, Prawo o zagranicznych agentach i jego znaczenie dla rosyjskiego społeczeństwa obywatelskiego na przykładzie ruchu LGBT, „Wschodnioznawstwo” 2016, s. 241-251.

52 Choć działacze skupieni w petersburskiej organizacji Rosyjska LGBT-sieć zwracają uwagę, że w ostatnich latach obserwują zauważalną poprawę stosunku opozycji pozaparlamentarnej dla postulatów środowiska LGBT oraz ich widocznej obecności na wspólnych demonstracjach. 


\section{Homophobia in codes of law. On the relations between legislation, discourse and social attitudes in Russia}

Summary

The main purpose of this paper is to present the Russian legislation in terms of its relations to homosexuals in the last twenty years.

The great emphasis was placed on the last eight years, when in eleven political units of Russian Federation the promotion of homosexuality to minors was banned. The author endeavours to understand how homophobic regulations influenced, reported in recent years, decrease in acceptance of sexual minorities.

The next essential part of this article is discussion on consequences of an act passed in June 2013 about protection of minors against propaganda of non-traditional sexual relations, increase of violence against homosexuals, discrimination of teachers, putting back on the agenda rights of Russian LGBT community and accusations against sexual minorities of detriment to the image of Russia. 